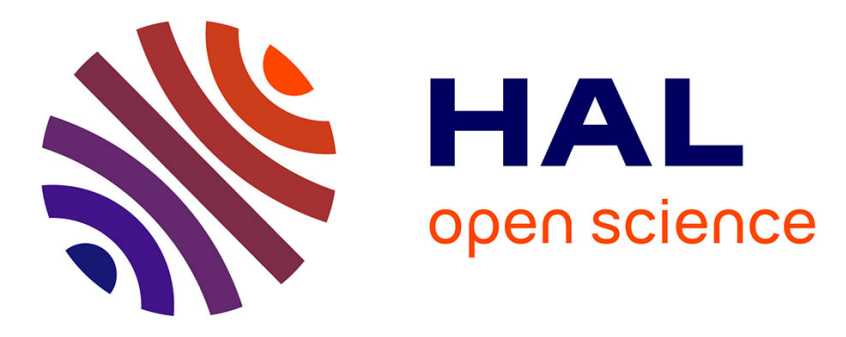

\title{
Crystallization-Induced Diastereoisomer Transformation of Dihydroartemisinic Aldehyde with the Betti Base
}

Andrea Zanetti, Pauline Chaumont-Olive, Geoffrey Schwertz, Marllon

Nascimento de Oliveira, Mario Andrés Gómez Fernández, Zacharias Amara, Janine Cossy

\section{To cite this version:}

Andrea Zanetti, Pauline Chaumont-Olive, Geoffrey Schwertz, Marllon Nascimento de Oliveira, Mario Andrés Gómez Fernández, et al.. Crystallization-Induced Diastereoisomer Transformation of Dihydroartemisinic Aldehyde with the Betti Base. Organic Process Research and Development, 2020, 24 (5), pp.850-855. 10.1021/acs.oprd.9b00481 . hal-03197851

\section{HAL Id: hal-03197851 \\ https://hal.science/hal-03197851}

Submitted on 3 Dec 2021

HAL is a multi-disciplinary open access archive for the deposit and dissemination of scientific research documents, whether they are published or not. The documents may come from teaching and research institutions in France or abroad, or from public or private research centers.
L'archive ouverte pluridisciplinaire HAL, est destinée au dépôt et à la diffusion de documents scientifiques de niveau recherche, publiés ou non, émanant des établissements d'enseignement et de recherche français ou étrangers, des laboratoires publics ou privés.

\section{(c)(1)}

Distributed under a Creative Commons Attribution| 4.0 International License 


\title{
Crystallization-Induced Diastereoisomer Transformation of Dihydroartemisinic Aldehyde with the Betti Base
}

\author{
Andrea Zanetti, ${ }^{\S}$ Pauline Chaumont-Olive, ${ }^{\S}$ Geoffrey Schwertz, Marllon Nascimento de Oliveira, \\ Mario Andrés Gomez Fernandez, Zacharias Amara,* and Janine Cossy*
}

Cite This: Org. Process Res. Dev. 2020, 24, 850-855

Read Online

ABSTRACT: Artemisinin is an important drug to fight malaria. It is produced either by extraction or via a semisynthetic route involving enzyme engineering. A key intermediate to produce artemisinin by the enzymatic route is dihydroartemisinic aldehyde (DHAAl). However, control of the absolute configuration of the stereocenter $\alpha$ to the aldehyde is highly challenging. Herein we report a protocol that allows the diastereomeric enrichment of a mixture of $(11 R) /(11 S)$-DHAAl to the desired (11R)-DHAAl by utilizing a crystallization-induced diastereomer transformation induced by the Betti base. In addition, the Betti base can be quantitatively recovered and reused after the reaction.

KEYWORDS: artemisinin, dihydroartemisinic aldehyde, CIDT, Betti base, deracemization

\section{INTRODUCTION}

Nearly half of the world population is at risk of malaria. In 2017, around 435000 deaths, mostly located in sub-Saharan African regions, were attributed to this disease. ${ }^{1}$ The fight against malaria therefore requires the efficient production of antimalarial drugs at a very low cost. Among these, artemisinin is considered to be one of the most potent drugs on the market, and this natural product is mainly obtained by extraction from Artemisia annua. However, the world market price is highly volatile, ranging from US $\$ 250$ to $\$ 1100$ per kilogram..$^{2}$ To complement the natural production and narrow the market price fluctuation, a semisynthetic process based on isoprenoid fermentation has been developed. ${ }^{3}$ This manufacturing route uses bioengineered microorganisms to produce advanced biosynthetic intermediates such as amorphadiene, ${ }^{4}$ artemisinic acid, ${ }^{3}$ and more recently dihydroartemisinic aldehyde (DHAAl) ${ }^{5}$ (Scheme 1). The last of these is a key product because it can be obtained directly by fermentation or by means of cost-competitive synthetic chemistry. ${ }^{6}$ However, one of the main drawbacks of these strategies is the control of the (11R)configuration of DHAAl, which is relatively unstable and this compound is usually obtained as a mixture of two diastereomers (Scheme 1). ${ }^{5}$

Optical resolution of racemates via the formation of diastereomers using enantiopure auxiliaries and their separation by crystallization is the preferred large-scale purification method to access highly diastereo- and enantioenriched compounds in pharmaceutical companies. ${ }^{7}$ One practical way to realize a diastereo- and enantioenrichment is to use a crystallizationinduced diastereomer transformation (CIDT), in which an epimerizable compound is converted into a crystalline diastereomer by condensation with a chiral auxiliary. ${ }^{8} \mathrm{~A}$ particularly useful method to realize CIDT relies on the use of the so-called "Betti base", which was first reported in $1900 .{ }^{9}$ In 2003, Košmrlj and Weigel demonstrated that racemic 2- ethylhexanal can be transformed to $(R)$-2-ethylhexanal by CIDT using trans-(1R,2R)-1-amino-6-nitroindan-2-ol. ${ }^{10}$ Additional examples have recently been reported in the literature, ${ }^{10-13}$ and Fülöp et al. showed that treatment of a racemic $\alpha$-substituted aldehyde with the Betti base leads to the formation of a naphthoxazine ring in which the 1- and 3-substituents are in a trans relationship ${ }^{14}$ and that the $(S)$-Betti base induces the formation of the $\left(1^{\prime} R, 3^{\prime} S\right)$-naphtoxazine. The epimerization of the stereocenter $\alpha$ to the aldehyde presumably occurs through an imine/enamine equilibrium (Scheme 2).

\section{RESULTS AND DISCUSSION}

In this study, gram-scale quantities of a mixture of $(11 R)$ - and (11S)-DHAAl with a diastereomeric ratio ( $\mathrm{dr}$ ) of 65:35 were prepared using a non-stereoselective reduction of artemisinic acid followed by oxidation. ${ }^{15}$ In order to improve this ratio, a mixture of $(11 R)$ - and (11S)-DHAAl was treated with the $(S)$ Betti base, which was identified as the correct enantiomer to access the desired diastereoenriched (11R)-DHAAl. Treatment of a 65:35 mixture of DHAAl diastereomers with $(S)-1-(\alpha$ aminobenzyl)-2-naphthol $[(S)-2]$ in methanol for $4 \mathrm{~h}$ at room temperature (rt) led to the formation of a mixture of naphtho[ $1,2-e][1,3]$ oxazines $\left(1^{\prime} R, 3^{\prime} S, 11 R\right)-3$ and $\left(1^{\prime} R, 3^{\prime} S, 11 S\right)-3$ in a ratio of $72: 28 .^{16}$ When the reaction was performed on a $0.545 \mathrm{mmol}$ scale, the yield of $\left(1^{\prime} R, 3^{\prime} S, 11 R\right)-3$ / $\left(1^{\prime} R, 3^{\prime} S, 11 S\right)-3$ was $63 \%$, and when the reaction was performed on a larger scale $(3.694 \mathrm{mmol})$, the yield of $\left(1^{\prime} R, 3^{\prime} S, 11 R\right)-3 /$ $\left(1^{\prime} R, 3^{\prime} S, 11 S\right)-3$ was increased to $83 \%$. The structures of these isomers were established by ${ }^{1} \mathrm{H}$ and ${ }^{13} \mathrm{C}$ NMR analysis, while

Special Issue: A Taste of Current French Organic Chemistry

Received: November 7, 2019

Published: January 14, 2020 
Scheme 1. Semisynthetic Approach toward the Synthesis of Dihydroartemisinic Aldehyde (DHAAl)

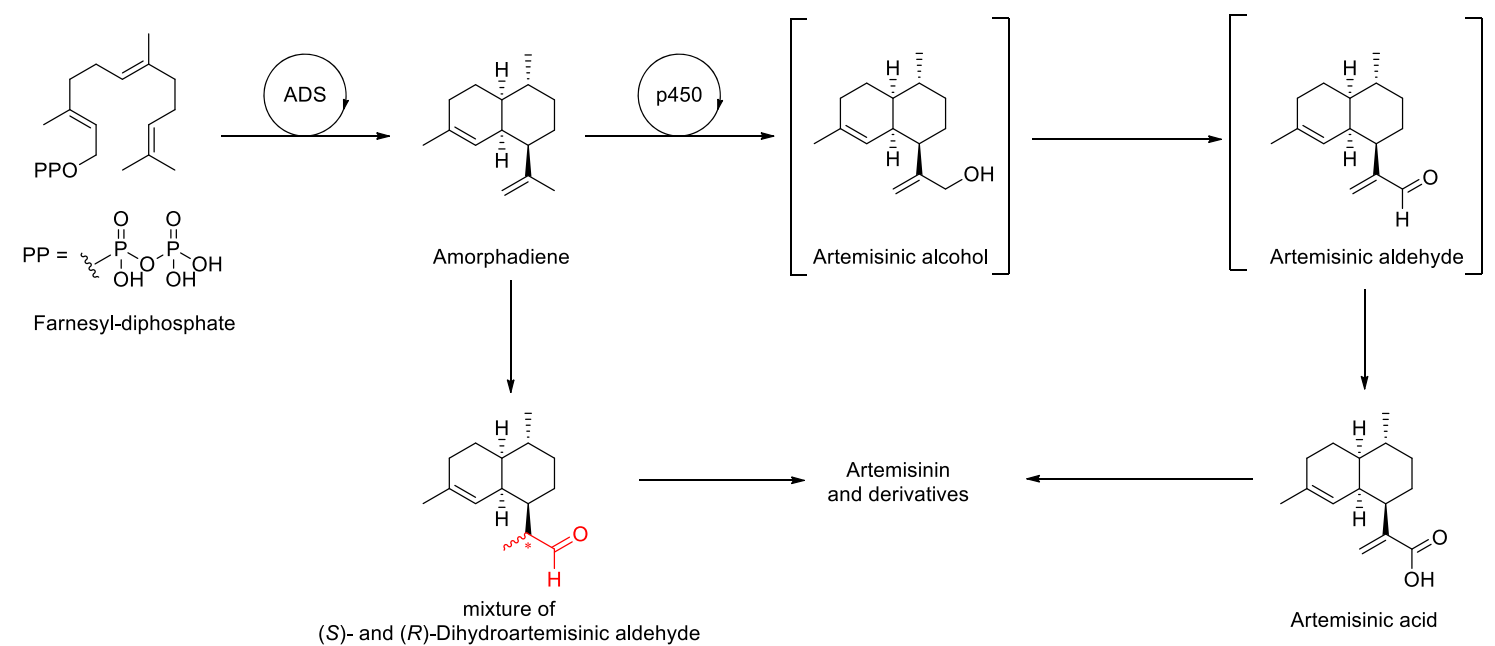

Scheme 2. Formation of One Naphthoxazine Diastereomer by Imine and Enamine Equilibrium<smiles>[R]C(C)C(=O)c1ccccc1</smiles><smiles></smiles>

nuclear Overhauser effect (NOE) experiments confirmed that for each isomer, the hydrogen atoms of the 1,3-oxazine ring at $\mathrm{C1}^{\prime}$ and $\mathrm{C}^{\prime}{ }^{\prime}$ are in a trans relationship. The independent preparation of $\left(1^{\prime} S, 3^{\prime} R, 11 R\right)-3$ by reaction of $(11 R)$-DHAAl with $(S)-2$ confirmed that the major isomer of the 72:28 mixture is the desired (11R)-isomer (Scheme 3).

When the $72: 28$ mixture of $\left(1^{\prime} R, 3^{\prime} S, 11 R\right)-3$ and $\left(1^{\prime} R, 3^{\prime} S, 11 S\right)-3$ was heated in refluxing methanol for an $4 \mathrm{~h}$, no change in the ratio was observed. However, when the same mixture was treated with acetic acid $(2.5 \mathrm{~mol} \%)$ for $3 \mathrm{~h}$ in methanol and heated at $65^{\circ} \mathrm{C}$, the $\left(1^{\prime} R, 3^{\prime} S, 11 S\right)-3$ diastereomer was obtained by filtration with a dr of 99:1 in $63 \%$ yield. In order to improve the yield of (11R)-DHAAl, a screening of solvents, temperatures, and times was performed, and the best conditions were to carry out the reaction at $65^{\circ} \mathrm{C}$ in acetonitrile for $92 \mathrm{~h}$ in the presence of $\mathrm{AcOH}$ (2.5 mol \%). Under these conditions, $\left(1^{\prime} R, 3^{\prime} S, 11 R\right)-3$ was isolated in $85 \%$ yield with a $\mathrm{dr}$ of $95: 5$ in favor of the $(11 R)$-isomer. Careful monitoring of the crude reaction mixture over time by ${ }^{1} \mathrm{H}$ NMR spectroscopy showed that the diastereomeric excess (de) increased with time in favor of the (11R)-isomer (Scheme 3$)$.

The crucial step was the hydrolysis of dihydronaphthoxazine 3 to isolate pure DHAAl and the recovery of the Betti base. Accordingly, treatment of $\left(1^{\prime} S, 3^{\prime} S, 11 R\right)-3$ with Dowex 50WX8$100(2 \mathrm{~g} / \mathrm{mmol})$ in the presence of a $2 \% \mathrm{TsOH}$ aqueous solution $(0.2 \mathrm{~mL} / \mathrm{mmol})$ in THF/EtOAc $(1: 1)$ at $\mathrm{rt}$ for $14 \mathrm{~h}$ led to the isolation of the desired (11R)-DHAAl epimer in quantitative yield with a dr of 95:5 (Scheme 4). A comparison of the $[\alpha]_{D}$ of
DHAAl obtained by CIDT with the $[\alpha]_{\mathrm{D}}$ of DHAAl prepared by reduction of dihydroartemisinic acid $(\mathrm{dr}>99: 1)$ followed by an oxidation step $\left(\mathrm{Py} \cdot \mathrm{SO}_{3}, \mathrm{Et}_{3} \mathrm{~N}, \mathrm{DMSO}\right)^{17}$ allowed us to attribute the $R$ absolute configuration of the $\mathrm{C} 11$ stereogenic center of DHAAl obtained by CIDT $\left[\left([\alpha]_{\mathrm{D}}^{25}+13, c 0.98, \mathrm{CHCl}_{3}\right.\right.$ from a sample obtained by CIDT with a dr of 95:5) versus $\left([\alpha]_{\mathrm{D}}^{25}+16, c\right.$ $0.98, \mathrm{CHCl}_{3}$ from a sample obtained by reduction and oxidation of pure dihydroartemisinic acid with an 11R/11S ratio of 99:1)]. It is worth mentioning that the Betti base can be easily recovered at the end of the process in quantitative yield ${ }^{18}$ and can be recycled in a new CIDT cycle. ${ }^{19}$

\section{CONCLUSION}

We developed a simple proof-of-concept protocol for the epimerization of the stereogenic center $\alpha$ to the aldehyde of DHAAl via a CIDT method utilizing the Betti base, which allowed the isolation of (11R)-DHAAl with a dr of 95:5 in a nonoptimized overall yield of $71 \%$ (three steps). The chiral auxiliary can be easily recovered and reused in another CIDT cycle. $^{18,19}$ This process can potentially offer an alternative to the current route to artemisinin involving hydrogenation, which utilizes an expensive optically active organometallic rhodium catalyst, to control the $(11 R)$ stereogenic center. ${ }^{3}$ CIDT could be an efficient route for the preparation of artemisinin on scale and open more economically viable alternatives to low-cost artemisinin manufacturing. 
Scheme 3. Synthesis of a 72:28 Mixture of Naphthoxazines 3 and Its Diastereoenrichment ${ }^{a}$<smiles>CC1=CC2C(C=O)CC[C@@H](C)[C@@H]2CC1</smiles>

$1(11-R / 11-S)=65: 35$
(S)-2

$83 \%$

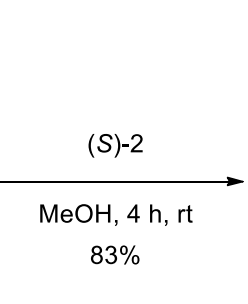

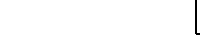

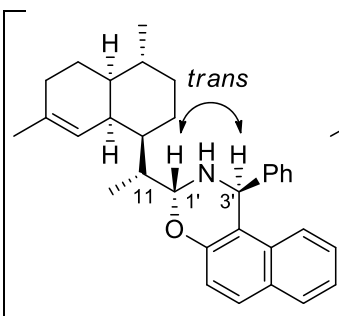

$\left(1^{\prime} R, 3^{\prime} S, 11 R\right)-3$

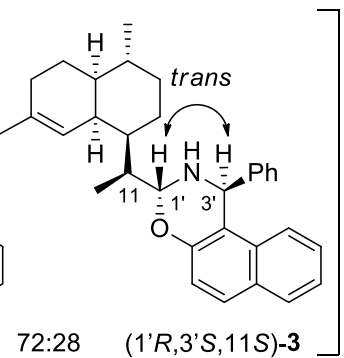

$\mathrm{AcOH}(2.5 \mathrm{~mol} \%)$

$\mathrm{CH}_{3} \mathrm{CN}, 65^{\circ} \mathrm{C}, \mathrm{t}(\mathrm{h})$

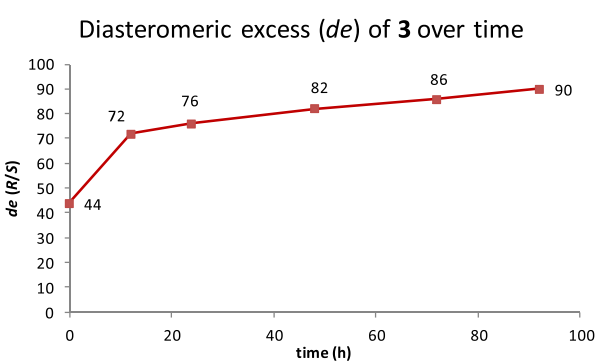

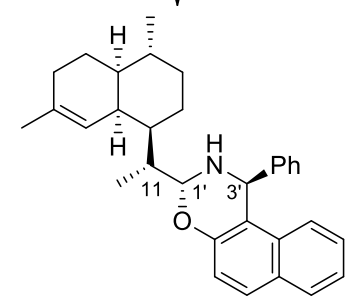

(1'R,3'S,11R)-3/(1'R,3'S,11S)-3

$(d e=90 \%$ after $92 \mathrm{~h})$

${ }^{a}$ A mixture of naphthoxazines $3(11 R / 11 S=72: 28)(30 \mathrm{mg}, 0.133 \mathrm{mmol}, 1$ equiv $)$ was suspended in $\mathrm{CH}_{3} \mathrm{CN}(0.4 \mathrm{~mL})$. AcOH $(2 \mu \mathrm{L}$ from a $10 \%$ solution in $\mathrm{MeCN}, 2.5 \mathrm{~mol} \%$ ) was added, and the suspension was stirred at $65{ }^{\circ} \mathrm{C}$ for the indicated times. The white suspension was solubilized in $\mathrm{CHCl}_{3}(1 \mathrm{~mL})$, and the solution was concentrated under reduced pressure. The diastereomeric excess (de) of 3 was measured by ${ }^{1} \mathrm{H} \mathrm{NMR}$ spectroscopy of the crude mixture by integration of the aminal protons.

Scheme 4. Synthesis of Naphthoxazine 3 and Isolation of Diastereoenriched DHAAl Using the Betti Base [(S)-2]<smiles>CC1=C[C@@H]2[C@H](CC=O)CCC[C@H]2CCC1</smiles>

$1(11-R / 11 S)=65: 35$<smiles>NC(c1ccccc1)c1c(O)ccc2ccccc12</smiles>

$(S)-2$

$\underset{83 \%}{\mathrm{MeOH}, \mathrm{rt}, 4 \mathrm{~h}}$

$83 \%$

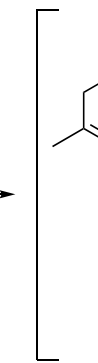<smiles>CC1=C[C@@H]2[C@H](CC1)CC[C@H]2[C@H]([14CH3])[C@@H]1N[C@@H](c2ccccc2)c2c(ccc3ccccc23)O1</smiles>

$\left(1^{\prime} R, 3^{\prime} S, 11 R\right)-3$<smiles>CC1=C[C@@H]2[C@@H](CC1)CC[C@H]2C(C)[C@@H]1N[C@H](c2ccccc2)c2c(ccc3ccccc23)O1</smiles>

$\left(1^{\prime} R, 3^{\prime} S, 11 S\right)-3$

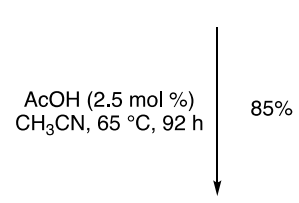

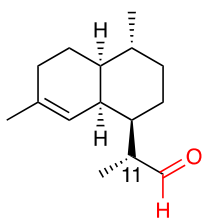

$1(11 R / 11 S)=95: 5$

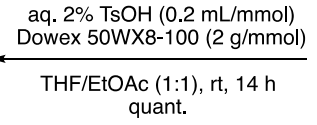

quant.

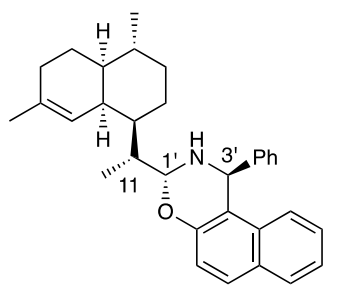

$\left.\left(1^{\prime} R, 3^{\prime} S, 11 R\right)-3 / 1^{\prime} R, 3^{\prime} S, 11 S\right)-3=95: 5$

\section{EXPERIMENTAL SECTION}

General Information. Reagents were purchased from Aldrich as reagent grade and used without further purification. Dowex 50WX8-100 was also purchased from Aldrich. Reactions were performed in oven-dried glassware under an argon atmosphere. The solvent compositions are reported individually in parentheses. Analytical thin-layer chromatography (TLC) was performed on aluminum sheets coated with silica gel $60 \mathrm{~F}_{254}$ 
(Merck, Macherey-Nagel) or with silica gel 60 RP-18 $\mathrm{F}_{254 \mathrm{~s}}$ (Merck, Macherey-Nagel). Visualization was achieved using an alkaline aqueous solution of potassium permanganate. Evaporation of solvents in vacuo was performed at $25-35^{\circ} \mathrm{C}$ under 910 mbar. Reported yields refer to spectroscopically and chromatographically pure compounds that were dried under high vacuum (0.1-0.05 mbar) before analytical characterization. ${ }^{1} \mathrm{H}$ and ${ }^{13} \mathrm{C}$ NMR spectra were recorded on a Bruker $\mathrm{AV}$ 400 spectrometer at $400 \mathrm{MHz}\left({ }^{1} \mathrm{H}\right)$ or $101 \mathrm{MHz}\left({ }^{13} \mathrm{C}\right)$. Chemical shifts $(\delta)$ are reported in parts per million upfield using the residual deuterated solvent signals as internal references $\left(\mathrm{CDCl}_{3}: \delta_{\mathrm{H}}=7.26 \mathrm{ppm}, \delta_{\mathrm{C}}=77.16 \mathrm{ppm}\right)$. For ${ }^{1} \mathrm{H}$ NMR spectra, coupling constants $(J)$ are given in hertz, and the resonance multiplicity is described as $\mathrm{s}$ (singlet), $\mathrm{d}$ (doublet), $\mathrm{t}$ (triplet), pent (pentuplet), m (multiplet), or br (broad). All spectra were recorded at $298 \mathrm{~K}$. Infrared (IR) spectra were recorded on a Bruker Tensor 27 FT-IR spectrometer and are reported as wavenumbers $\tilde{\nu}$ in reciprocal centimeters. Highresolution mass spectrometry (HRMS) and analyses were performed by the Laboratoire de Spectrométrie de Masse at Sorbonne Université, Paris. Melting points were determined using a Büchi melting point apparatus in open capillaries. The enantiomeric ratios were determined by supercritical fluid chromatography (SFC) on a chiral stationary phase using a Minigram Berger SFC-Mettler Toledo apparatus; $i \mathrm{PrOH}$ was used as the polar eluent. Nomenclature follows the suggestions proposed by the software ChemDraw Professional 16.0.

$(1 S, 3 R)-3-((R)-1-((1 R, 4 R, 4 \mathrm{a} S, 8 \mathrm{a} S)-4,7-D i m e t h y l-$ 1,2,3,4,4a,5,6,8a-octahydronaphthalen-1-yl)ethyl)-1phenyl-2,3-dihydro-1 $H$-naphtho[1,2-e][1,3]oxazine [(1'R,3'S, 11R)-3]. Diastereoenriched dihydroartemisinic aldehyde $(11 R / 11 S=99: 1,67 \mathrm{mg}, 0.304 \mathrm{mmol}, 1$ equiv $)$ was added to a suspension of $(S)$-Betti base $(75 \mathrm{mg}, 0.301 \mathrm{mmol}, 0.99$ equiv) in $\mathrm{MeOH}(1.3 \mathrm{~mL})$, and the suspension was stirred at 23 ${ }^{\circ} \mathrm{C}$. After $4 \mathrm{~h}$, the white solid was collected by vacuum filtration, washed with ice-cooled $\mathrm{MeOH}(2 \times 0.4 \mathrm{~mL})$, and dried under reduced pressure to afford the corresponding naphthoxazine as a white solid (79 mg, 58\%). Mp: $145-146{ }^{\circ} \mathrm{C}(\mathrm{MeOH}) .[\alpha]_{\mathrm{D}}^{25}$ -24 (c 0.92, $\mathrm{CHCl}_{3}$ ). IR (ATR): $\tilde{\nu}=2907,1621,1598,1514$, 1448, 1389, 1233, 967, 918, 809, 743, $699 \mathrm{~cm}^{-1} .{ }^{1} \mathrm{H}$ NMR (400 $\left.\mathrm{MHz}, \mathrm{CDCl}_{3}\right): \delta 7.78(\mathrm{~m}, 1 \mathrm{H}), 7.74(\mathrm{~d}, J=9.0 \mathrm{~Hz}, 1 \mathrm{H}), 7.43$ $(\mathrm{m}, 1 \mathrm{H}), 7.34-7.20(\mathrm{~m}, 7 \mathrm{H}), 7.12(\mathrm{~d}, J=8.9 \mathrm{~Hz}, 1 \mathrm{H}), 5.58(\mathrm{~s}$, $1 \mathrm{H}), 5.22(\mathrm{br} \mathrm{s}, 1 \mathrm{H}), 4.82(\mathrm{~d}, J=3.0 \mathrm{~Hz}, 1 \mathrm{H}), 2.50(\mathrm{~m}, \mathrm{NH}, 1 \mathrm{H})$, 2.46 (br s, $1 \mathrm{H}), 2.03(\mathrm{~m}, 1 \mathrm{H}), 1.97-1.73(\mathrm{~m}, 3 \mathrm{H}), 1.61$ (br s, $3 \mathrm{H}), 1.54-1.16(\mathrm{~m}, 5 \mathrm{H}), 1.02(\mathrm{~d}, J=6.9 \mathrm{~Hz}, 3 \mathrm{H}), 0.83(\mathrm{~d}, J=$ $6.2 \mathrm{~Hz}, 3 \mathrm{H}), 0.76-0.64(\mathrm{~m}, 3 \mathrm{H}) .{ }^{13} \mathrm{C} \mathrm{NMR}\left(101 \mathrm{MHz} \mathrm{CDCl}_{3}\right)$ : $\delta 153.5,142.9,135.4,132.1,129.4(2 \mathrm{C}), 129.2,128.60,128.59$, 128.0 (2C), 127.2, 126.7, 123.2, 123.0, 120.7, 119.5, 115.0, 83.7, 53.7, 42.8, 42.1, 37.4, 37.2, 35.4, 27.8, 26.8, 26.0, 25.5, 24.0, 19.9, 9.8. HR-ESI-MS: $m / z$ calcd for $\mathrm{C}_{32} \mathrm{H}_{37} \mathrm{NOH}^{+}, 452.2948$; found, $452.2939[\mathrm{M}+\mathrm{H}]^{+}$.

$(1 S, 3 R)-3-((R: S=72: 28)-1-((1 R, 4 R, 4 \mathrm{a} S, 8 \mathrm{a} S)-4,7-\mathrm{Di}-$ methyl-1,2,3,4,4a,5,6,8a-octahydronaphthalen-1-yl)ethyl)-1-phenyl-2,3-dihydro-1 $H$-naphtho[1,2-e][1,3]oxazine [72:28 $\left.\left(1^{\prime} R, 3^{\prime} S, 11 R\right)-3 /\left(1^{\prime} R, 3^{\prime} S, 11 S\right)-3\right]$. Dihydroartemisinic aldehyde $(11 R / 11 S=65: 35,814 \mathrm{mg}, 3.694$ mmol, 1 equiv) was added to a suspension of $(S)$-Betti base $(875$ $\mathrm{mg}, 3.509 \mathrm{mmol}, 0.95$ equiv) in $\mathrm{MeOH}(16 \mathrm{~mL})$, and the suspension was stirred at $23{ }^{\circ} \mathrm{C}$ for $4 \mathrm{~h}$. The white solid was collected by vacuum filtration, washed with ice-cooled $\mathrm{MeOH}$ $(2 \times 2 \mathrm{~mL})$, and dried under reduced pressure to afford the corresponding naphthoxazines in an $11 R / 11 S$ ratio of $72: 28$ as a white solid (1.317 g, 83\%). ${ }^{1} \mathrm{H} \mathrm{NMR}\left(400 \mathrm{MHz}, \mathrm{CDCl}_{3}\right): \delta 7.78$ $(\mathrm{m}, 1 \mathrm{H}),[7.74(\mathrm{~d}, J=8.8 \mathrm{~Hz}$, major $)$ and $7.69(\mathrm{~m}$, minor $), 1 \mathrm{H}]$, $7.34-7.18(\mathrm{~m}, 7 \mathrm{H}), 7.12(\mathrm{~d}, J=8.9 \mathrm{~Hz}, 1 \mathrm{H}), 5.58(\mathrm{~s}, 1 \mathrm{H}),[5.22$ (br s, $0.72 \mathrm{H})$ and $4.91($ br s, $0.28 \mathrm{H})],[4.82(\mathrm{~d}, J=3.0 \mathrm{~Hz}$, $0.72 \mathrm{H})$ and $4.79(\mathrm{~m}, 0.28 \mathrm{H})], 2.50(\mathrm{~m}, \mathrm{NH}, 1 \mathrm{H}), 2.46(\mathrm{br} \mathrm{s}$, $1 \mathrm{H}), 2.04(\mathrm{~m}, 1 \mathrm{H}), 1.97-1.73(\mathrm{~m}, 3 \mathrm{H}),[1.61$ (br s, major) and 1.45 (br s, minor), $3 \mathrm{H}], 1.56-1.16(\mathrm{~m}, 5 \mathrm{H}), 1.02(\mathrm{~d}, J=6.9 \mathrm{~Hz}$, $3 \mathrm{H}),[0.85(\mathrm{~d}, J=6.6 \mathrm{~Hz}$, minor $)$ and $0.83(\mathrm{~d}, J=6.2 \mathrm{~Hz}$, major $)$, $3 \mathrm{H}], 0.73-0.64(\mathrm{~m}, 3 \mathrm{H}) \cdot{ }^{13} \mathrm{C}$ NMR $\left(101 \mathrm{MHz}, \mathrm{CDCl}_{3}\right): \delta$ [153.5 (major), 153.2 (minor)], [143.0 (minor), 142.9 (major)], [135.3 (major), 134.7 (minor)], [132.1 (major), 131.99 (minor) ], [129.39 (major, 2C), 129.3 (minor, 2C)], [129.2 (major), 129.0 (minor)], [128.7 (minor), 128.60 (major)], [128.59 (major), 128.5 (minor)], [128.3 (minor, 2C), 128.0 (major, 2C)], [127.2 (major), 127.1 (minor)], [126.7 (major), 126.6 (minor)], [123.2 (major), 123.1 (minor)], 123.0, [120.8 (minor), 120.7 (major)], [119.6 (minor), 119.5 (major)], [115.0 (major), 114.9 (minor)], [83.7 (major), 82.8 (minor)], [54.4 (minor), 53.7 (major)], 42.8, [42.14 (major), 42.0 (minor)], [39.0 (minor), 37.2 (major)], [38.4 (minor), 37.4 (major)], [35.9 (minor), 35.4 (major) ], [28.0 (minor), 27.8 (major)], [26.8 (major), 26.6 (minor) ], [26.4 (minor), 26.0 (major)], [25.8 (minor), 25.5 (major) ], [24.00 (major), 23.8 (minor)], [20.0 (minor), 19.9 (major)], [11.3 (minor), 9.8 (major)].

$(1 S, 3 R)-3-((R)-1-((1 R, 4 R, 4 a S, 8 a S)-4,7-D i m e t h y l-$ 1,2,3,4,4a,5,6,8a-octahydronaphthalen-1-yl)ethyl)-1phenyl-2,3-dihydro-1 $H$-naphtho[1,2-e][1,3]oxazine [95:5 $\left.\left(1^{\prime} R, 3^{\prime} S, 11 R\right)-3 /\left(1^{\prime} R, 3^{\prime} S, 11 S\right)-3\right]$. A mixture of naphthoxazines $(11 R / 11 S=72: 28,150 \mathrm{mg}, 0.332 \mathrm{mmol}, 1$ equiv $)$ was suspended in $\mathrm{CH}_{3} \mathrm{CN}(2 \mathrm{~mL})$. $\mathrm{AcOH}\left(10 \%\right.$ in $\mathrm{CH}_{3} \mathrm{CN}, 9$ $\mu \mathrm{L}, 2.5 \mathrm{~mol} \%$ ) was added, and the suspension was stirred at 65 ${ }^{\circ} \mathrm{C}$ for $92 \mathrm{~h}$. The white suspension was solubilized in $\mathrm{CHCl}_{3}(5$ $\mathrm{mL})$, washed with a saturated aqueous solution of $\mathrm{NaHCO}_{3}(2$ $\mathrm{mL})$ and brine $(2 \mathrm{~mL})$, dried over $\mathrm{Na}_{2} \mathrm{SO}_{4}$, filtered, and concentrated under reduced pressure to afford a white solid. The solid was suspended in methanol $(1 \mathrm{~mL})$, filtered, and washed with ice-cooled methanol $(0.5 \mathrm{~mL})$. The residue was dried under reduced pressure to afford the naphthoxazines in an $11 \mathrm{R} / 11 \mathrm{~S}$ ratio of $95: 5$ as a white solid $(85 \%, 127 \mathrm{mg}) . \mathrm{Mp}: 149-153{ }^{\circ} \mathrm{C}$ $(\mathrm{MeOH}) .[\alpha]_{\mathrm{D}}^{25}-19\left(\right.$ c $\left.0.68, \mathrm{CHCl}_{3}\right) .{ }^{1} \mathrm{H}$ NMR $(400 \mathrm{MHz}$, $\left.\mathrm{CDCl}_{3}\right): \delta 7.78-7.74(\mathrm{~m}, 2 \mathrm{H}), 7.45-7.19(\mathrm{~m}, 8 \mathrm{H}), 7.12(\mathrm{~d}, J=$ $8.9 \mathrm{~Hz}, 1 \mathrm{H}), 5.58(\mathrm{~s}, 1 \mathrm{H}),[5.22(\mathrm{br} \mathrm{s}, 0.95 \mathrm{H})$ and 4.91 (br s, $0.05 \mathrm{H})],[4.82(\mathrm{~d}, J=3.0 \mathrm{~Hz}, 0.95 \mathrm{H})$ and $4.79(\mathrm{~d}, J=3.0 \mathrm{~Hz}$, $0.05 \mathrm{H})], 2.50(\mathrm{~m}, \mathrm{NH}, 1 \mathrm{H}), 2.46(\mathrm{br} \mathrm{s}, 1 \mathrm{H}), 2.08-1.73(\mathrm{~m}$, $4 \mathrm{H}), 1.61$ (br s, $3 \mathrm{H}), 1.56-1.18(\mathrm{~m}, 5 \mathrm{H}), 1.02(\mathrm{~d}, J=6.9 \mathrm{~Hz}$, $3 \mathrm{H}),[0.85(\mathrm{~d}, J=6.6 \mathrm{~Hz}$, minor $)$ and $0.83(\mathrm{~d}, J=6.2 \mathrm{~Hz}$, major $)$, $3 \mathrm{H}], 0.75-0.64(\mathrm{~m}, 3 \mathrm{H}) .{ }^{13} \mathrm{C} \mathrm{NMR}\left(101 \mathrm{MHz}, \mathrm{CDCl}_{3}\right): \delta$ 153.5, 142.9, 135.4, 132.1, 129.4 (2C), 129.2, 128.60, 128.59, 128.0 (2C), 127.2, 126.7, 123.2, 123.0, 120.7, 119.5, 115.0, 83.7, 53.7, 42.8, 42.1, 37.4, 37.2, 35.4, 27.8, 26.8, 26.0, 25.5, 24.0, 19.9, 9.8 .

(R)-2-((1R,4R,4aS,8aS)-4,7-Dimethyl-1,2,3,4,4a,5,6,8aoctahydronaphthalen-1-yl)propanal [95:5 (11R)-1/(11S)1]. The naphthoxazines $(11 \mathrm{R} / 11 \mathrm{~S}=95: 5,127 \mathrm{mg}, 0.281 \mathrm{mmol})$ were dissolved in a 1:1 THF/EtOAc solution $(1.12 \mathrm{~mL})$. The solution was treated with Dowex 50WX8-100 (0.562 g, $2 \mathrm{~g} /$ $\mathrm{mmol})$ and a $2 \% \mathrm{TsOH}$ aqueous solution $(0.056 \mathrm{~mL}, 0.2 \mathrm{~mL} /$ $\mathrm{mmol}$ ). The suspension was stirred at $23{ }^{\circ} \mathrm{C}$. After $14 \mathrm{~h}$, the suspension was filtered under vacuum, and the brown residue was washed with $\mathrm{Et}_{2} \mathrm{O}(1.12 \mathrm{~mL} \times 3,6 \mathrm{~mL} / \mathrm{g}$ of resin $)$. The organic layer was cooled with a water/ice bath and washed with a saturated aqueous solution of $\mathrm{Na}_{2} \mathrm{CO}_{3}(2 \times 3 \mathrm{~mL})$. The organic layer was washed with water $(2 \times 3 \mathrm{~mL})$ and brine $(2 \times 3$ 
$\mathrm{mL}$ ), dried over $\mathrm{Na}_{2} \mathrm{SO}_{4}$, filtered, and concentrated under reduced pressure. The crude residue was filtered on silica gel (85:15 hexanes/EtOAc) to afford dihydroartemisinic aldehyde as a colorless oil (62 mg, quantitative yield). $R_{\mathrm{f}}=0.78\left(\mathrm{SiO}_{2} ; 9: 1\right.$ petroleum ether/EtOAc). $[\alpha]_{\mathrm{D}}^{25}+13\left(\mathrm{c} 0.98, \mathrm{CHCl}_{3}\right)$. IR (ATR): $\tilde{\nu}=2912,2868,1706,1449,1377,1289,1264,1165$, 1110, 1078, 1032, $990 \mathrm{~cm}^{-1} .{ }^{1} \mathrm{H}$ NMR $\left(400 \mathrm{MHz}, \mathrm{CDCl}_{3}\right): \delta$ [9.63 (d, $J=4.0 \mathrm{~Hz}, 0.05 \mathrm{H})$ and $9.57(\mathrm{~d}, J=4.0 \mathrm{~Hz}, 0.95 \mathrm{H})$ ], [5.27 (br s, 0.05H) and 5.13 (br s, 0.95H)], $2.48($ br s, 1H), 2.36 (m, $1 \mathrm{H}), 2.00-1.76(\mathrm{~m}, 3 \mathrm{H}), 1.64(\mathrm{br} \mathrm{s}, 3 \mathrm{H}), 1.62-1.22(\mathrm{~m}$, $6 \mathrm{H}), 1.12\left(\mathrm{ddd}_{\mathrm{app}}, J_{\mathrm{AB}}=3.3,13.0,25.0 \mathrm{~Hz}, 1 \mathrm{H}\right), 1.06(\mathrm{~d}, J=7.0$ $\mathrm{Hz}, 3 \mathrm{H}), 0.95\left(\mathrm{ddd}_{\mathrm{app}}, J_{\mathrm{AB}}=3.2,12.1,26.0 \mathrm{~Hz}, 1 \mathrm{H}\right), 0.87(\mathrm{~d}, J=$ $6.5 \mathrm{~Hz}, 3 \mathrm{H}) .{ }^{13} \mathrm{C} \mathrm{NMR}\left(101 \mathrm{MHz}, \mathrm{CDCl}_{3}\right): \delta 206.2$, 136.2, 119.7, 48.6, 42.0, 41.6, 36.7, 35.4, 27.8, 27.5, 26.7, 25.9, 24.0, 19.8, 11.9. $t_{\mathrm{R}}: 2.84$ and $3.07 \mathrm{~min}$ (93:7) (SFC, OD-H column, $100 \mathrm{bar}, 4 \mathrm{~mL} / \mathrm{min}$, isocratic gradient 99:1 $\left.\mathrm{CO}_{2} / \mathrm{iPrOH}\right)$. HRESI-MS: $m / z$ calcd for $\mathrm{C}_{15} \mathrm{H}_{24} \mathrm{OH}^{+}, 221.1900$; found, 221.1899 $[\mathrm{M}+\mathrm{H}]^{+}$.

Synthesis of $(R)-2-[(1 R, 4 R, 4 \mathrm{aS}, 8 \mathrm{a} S)-4,7-D i m e t h y l-$

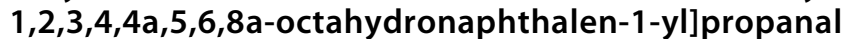
(DHAAl) from Dihydroartemisinic Alcohol. Dihydroartemisinic alcohol ( $\mathrm{dr}>$ 98:2, $99 \mathrm{mg}, 0.450 \mathrm{mmol}, 1$ equiv), obtained by $\mathrm{LiAlH}_{4}$ reduction of dihydroartemisinic acid, was dissolved in $\mathrm{CH}_{2} \mathrm{Cl}_{2}(2 \mathrm{~mL})$ and DMSO $(0.5 \mathrm{~mL})$. The mixture was cooled to $-10^{\circ} \mathrm{C}$ with an ice $/ \mathrm{NaCl}$ bath and slowly treated with $\mathrm{Et}_{3} \mathrm{~N}$ (0.25 mL, $1.80 \mathrm{mmol}, 4$ equiv). $\mathrm{Py} \cdot \mathrm{SO}_{3}(179 \mathrm{mg}$, $1.124 \mathrm{mmol}, 2.5$ equiv) was added in three portions over $20 \mathrm{~min}$. The mixture was allowed to warm to $23^{\circ} \mathrm{C}$ and stirred for $16 \mathrm{~h}$. GC/MS analysis showed full conversion of dihydroartemisinic alcohol to DHAAl. The mixture was treated with citric acid (aq, $10 \%, 2 \mathrm{~mL}$ ) and stirred for $10 \mathrm{~min}$. The layers were then separated, and the organic layer was washed with citric acid (aq, $10 \%, 2 \mathrm{~mL})$, a saturated aqueous solution of $\mathrm{NaHCO}_{3}(2 \mathrm{~mL})$, and brine $(4 \mathrm{~mL})$, dried over $\mathrm{Na}_{2} \mathrm{SO}_{4}$, filtered, and concentrated under reduced pressure. The yellow residue was filtered on silica gel (85:15 hexanes/EtOAc) to afford DHAAl as a colorless oil ( $81 \mathrm{mg}, 82 \%)$. It is worth mentioning that when the reaction was performed on $300 \mathrm{mg}$ of dihydroartemisinic alcohol, DHAAl was obtained in 97\% yield. $R_{\mathrm{f}}=0.78\left(\mathrm{SiO}_{2} ; 9: 1\right.$ petroleum ether/ EtOAc). $[\alpha]_{\mathrm{D}}^{25}+16\left(c 0.98, \mathrm{CHCl}_{3}\right) .{ }^{1} \mathrm{H}$ NMR $(400 \mathrm{MHz}$, $\left.\mathrm{CDCl}_{3}\right): \delta 9.57(\mathrm{~d}, J=4.0 \mathrm{~Hz}, 1 \mathrm{H}), 5.13($ br s, $1 \mathrm{H}), 2.48$ (br s, $1 \mathrm{H}), 2.36(\mathrm{~m}, 1 \mathrm{H}), 2.00-1.76(\mathrm{~m}, 3 \mathrm{H}), 1.64(\mathrm{br} \mathrm{s}, 3 \mathrm{H}), 1.66-$ $1.22(\mathrm{~m}, 6 \mathrm{H}), 1.12\left(\mathrm{ddd}_{\mathrm{app}}, J_{\mathrm{AB}}=3.2,12.6,25.1 \mathrm{~Hz}, 1 \mathrm{H}\right), 1.06$ $(\mathrm{d}, J=7.0 \mathrm{~Hz}, 3 \mathrm{H}), 0.95\left(\mathrm{ddd}_{\mathrm{app}}, J_{\mathrm{AB}}=3.2,12.2,26.1 \mathrm{~Hz}, 1 \mathrm{H}\right)$, $0.87(\mathrm{~d}, J=6.5 \mathrm{~Hz}, 3 \mathrm{H}) .{ }^{13} \mathrm{C} \mathrm{NMR}\left(101 \mathrm{MHz}, \mathrm{CDCl}_{3}\right): \delta 206.2$, 136.2, 119.7, 48.6, 42.0, 41.6, 36.7, 35.4, 27.8, 27.5, 26.7, 25.9, 24.0, 19.8, 11.9. $t_{\mathrm{R}}: 2.84 \mathrm{~min}$ (SFC, OD-H column, 100 bar, 4 $\mathrm{mL} / \mathrm{min}$, isocratic gradient 99:1 $\left.\mathrm{CO}_{2} / \mathrm{PrOH}\right)$.

Recovery of the Betti Base. The solid residue, Dowex/ Betti base $(562 \mathrm{mg})$, was suspended in THF $(1.23 \mathrm{~mL})$, and then $\mathrm{MeOH}(0.15 \mathrm{~mL})$ was added, followed by the addition of a $28 \% \mathrm{NH}_{4} \mathrm{OH}$ aqueous solution $(0.31 \mathrm{~mL})$. The mixture was stirred for $45 \mathrm{~min}$ at $\mathrm{rt}$. After filtration, the filtrate was washed with THF $(3 \times 1 \mathrm{~mL})$, and the solvents were evaporated under reduced pressure. The Betti base was recovered in quantitative yield as a white solid ( $70 \mathrm{mg}, 0.281 \mathrm{mmol}) . \mathrm{Mp}$ : $130-131{ }^{\circ} \mathrm{C}$ (lit. $\left.{ }^{1} 133-134{ }^{\circ} \mathrm{C}\right) \cdot[\alpha]_{\mathrm{D}}^{25}+93.0\left(c 0.42, \mathrm{CHCl}_{3}\right)\left[\right.$ lit. $^{20}+94.1(c$ 1.0, $\left.\mathrm{CHCl}_{3}\right)$ ].

\section{ASSOCIATED CONTENT}

\section{SI Supporting Information}

The Supporting Information is available free of charge at https://pubs.acs.org/doi/10.1021/acs.oprd.9b00481.
Stability of DHAAl and naphthoxazines under basic and acidic conditions, ${ }^{1} \mathrm{H}$ and ${ }^{13} \mathrm{C}$ NMR spectra, and SFC chromatograms (PDF)

\section{AUTHOR INFORMATION}

\section{Corresponding Authors}

Zacharias Amara - Conservatoire national des arts et métiers, HESAM Universite, Paris, France; (1) orcid.org/ 0000-0001-6824-1116; Phone: +33 1402726 14;

Email: zacharias.amara@lecnam.net

Janine Cossy - ESPCI Paris/CNRS/PSL Research University, Paris, France; (1) orcid.org/0000-0001-87469239; Phone: +33 1407944 29; Email: janine.cossy@ espci.fr; Fax: +33140794454

\section{Other Authors}

Andrea Zanetti - ESPCI Paris/CNRS/PSL Research University, Paris, France

Pauline Chaumont-Olive - ESPCI Paris/CNRS/PSL Research University, Paris, France

Geoffrey Schwertz - ESPCI Paris/CNRS/PSL Research University, Paris, France

Marllon Nascimento de Oliveira - Conservatoire national des arts et métiers, HESAM Université, Paris, France

Mario Andrés Gomez Fernandez - Conservatoire national des arts et métiers, HESAM Université, Paris, France

Complete contact information is available at:

https://pubs.acs.org/10.1021/acs.oprd.9b00481

\section{Author Contributions}

${ }^{\S}$ A.Z. and P.C.-O. contributed equally.

\section{Funding}

This work was supported by the Bill \& Melinda Gates Foundation [OPP1190174].

\section{Notes}

The authors declare no competing financial interest.

\section{ACKNOWLEDGMENTS}

We thank Dr. Kai Rossen and Dr. Trevor Laird for their advice and fruitful discussions and Dr. Fabienne Dioury for synthesizing gram-scale quantities of the key biosynthetic precursors required for this study.

\section{REFERENCES}

(1) World Malaria Report 2018; World Health Organization: Geneva, 2018.

(2) Peplow, M. Synthetic malaria drug meets market resistance. Nature 2016, 530, 389-390.

(3) Paddon, C. J.; Westfall, P. J.; Pitera, D. J.; Benjamin, K.; Fisher, K.; McPhee, D.; Leavell, M. D.; Tai, A.; Main, A.; Eng, D.; Polichuk, D. R.; Teoh, K. H.; Reed, D. W.; Treynor, T.; Lenihan, J.; Jiang, H.; Fleck, M.; Bajad, S.; Dang, G.; Dengrove, D.; Diola, D.; Dorin, G.; Ellens, K. W.; Fickes, S.; Galazzo, J.; Gaucher, S. P.; Geistlinger, T.; Henry, R.; Hepp, M.; Horning, T.; Iqbal, T.; Kizer, L.; Lieu, B.; Melis, D.; Moss, N.; Regentin, R.; Secrest, S.; Tsuruta, H.; Vazquez, R.; Westblade, L. F.; Xu, L.; Yu, M.; Zhang, Y.; Zhao, L.; Lievense, J.; Covello, P. S.; Keasling, J. D.; Reiling, K. K.; Renninger, N. S.; Newman, J. D. High-level semisynthetic production of the potent antimalarial artemisinin. Nature 2013, 496, 528-532. (b) Turconi, J.; Griolet, F.; Guevel, R.; Oddon, 
G.; Villa, R.; Geatti, A.; Hvala, M.; Rossen, K.; Göller, R.; Burgard, A. Semisynthetic artemisinin, the chemical path to industrial production. Org. Process Res. Dev. 2014, 18, 417-422.

(4) (a) Westfall, P. J.; Pitera, D. J.; Lenihan, J. R.; Eng, D.; Woolard, F. X.; Regentin, R.; Horning, T.; Tsuruta, H.; Melis, D. J.; Owens, A.; Fickes, S.; Diola, D.; Benjamin, K. R.; Keasling, J. D.; Leavell, M. D.; McPhee, D. J.; Renninger, N. S.; Newman, J. D.; Paddon, C. J. Production of amorphadiene in yeast, and its conversion to dihydroartemisinic acid, precursor to the antimalarial agent artemisinin. Proc. Natl. Acad. Sci. U. S. A. 2012, 109, E111-E118. (b) Singh, D.; McPhee, D.; Paddon, C. J.; Cherry, J.; Maurya, G.; Mahale, G.; Patel, Y.; Kumar, N.; Singh, S.; Sharma, B.; Kushwaha, L.; Singh, S.; Kumar, A. Amalgamation of synthetic biology and chemistry fot high-throughput nonconventional synthesis of the antimalarial drug artemisinin. Org. Process Res. Dev. 2017, 21, 551-558.

(5) Demiray, M.; Tang, X.; Wirth, T.; Faraldos, J. A.; Allemann, R. K. An efficient chemoenzymatic synthesis of dihydroartemisinic aldehyde. Angew. Chem., Int. Ed. 2017, 56, 4347-4350.

(6) (a) Fisher, K.; McPhee, D.; Woolard, F. X. Processes for the preparation of artemisinin and its precursors. Patent WO2009088404A1, 2009. (b) Unpublished results.

(7) Rosini, G.; Paolucci, C.; Boschi, F.; Marotta, E.; Righi, P.; Tozzi, F. Acid promoted CIDT for the deracemization of dihydrocinnamic aldehydes with Betti's base. Green Chem. 2010, 12, 1747-1757.

(8) Brands, K. M. J.; Davies, A. J. Crystallization-induced diastereomer transformations. Chem. Rev. 2006, 106, 2711-2733.

(9) Betti, M. Sull' additione di basi aldeido aminiche ai naftoli. Gazz. Chim. Ital. 1900, 30, 310-316.

(10) Košmrlj, J.; Weigel, L. O.; Evans, D. A.; Downey, C. W.; Wu, J. Unfunctionalized, $\alpha$-epimerizable nonracemic ketones and aldehydes can be accessed by crystallization-induced dynamic resolution of imines. J. Am. Chem. Soc. 2003, 125, 3208-3209.

(11) Carella, A.; Ramos Ferronatto, G.; Marotta, E.; Mazzanti, A.; Righi, P.; Paolucci, C. Betti's base for crystallization-induced deracemization of substituted aldehydes: synthesis of enantiopure amorolfine and fenpropimorph. Org. Biomol. Chem. 2017, 15, 29682978.

(12) Cardellicchio, C.; Capozzi, M. A. M.; Naso, F. The Betti base: the awakening of a sleeping beauty. Tetrahedron: Asymmetry 2010, 21, 507-517.

(13) Srimannarayana, M.; Righi, P.; Marotta, E.; Paolucci, C. Deracemization and transacetalization of aldehydes with enantiomers of Betti's base derivatives. Synth. Commun. 2014, 44, 3450-3455.

(14) Szatmari, I.; Martinek, T. A.; Lazar, L.; Fulop, F. Substituent effects in the ring-chain tautomerism of 1,3-diaryl-2,3-dihydro- $1 \mathrm{H}$ naphth $[1,2-e][1,3]$ oxazines. Tetrahedron 2003, 59, 2877-2884.

(15) Reduction was carried out by following the procedure reported by Jung et al. See: Jung, M.; Li, X.; Bustos, D. A.; Elsohly, H. N.; McChesney, J. D.; Milhous, W. K. Synthesis and antimalarial activity of (+)-deoxoartemsinin. J. Med. Chem. 1990, 33, 1516-1518. This afforded a 65:35 diastereomeric mixture of the alcohol, which was then oxidized according to the procedure reported in ref 4 .

(16) The $\left(1^{\prime} R, 3^{\prime} S, 11 R\right)-3 /\left(1^{\prime} R, 3^{\prime} S, 11 S\right)-3$ ratio was established from ${ }^{1} \mathrm{H}$ NMR spectra of the filtered mixture recorded in $\mathrm{C}_{6} \mathrm{D}_{6}$ (see the Experimental Section).

(17) The $[\alpha]_{\mathrm{D}}^{25}$ of DHAAl is not reported in the literature.

(18) The recovery of the Betti base varied between $75 \%$ (use of $\mathrm{Et}_{3} \mathrm{~N}$ ) and $99 \%$ (use of a $28 \%$ aqueous solution of $\mathrm{NH}_{4} \mathrm{OH}$ ).

(19) When DHAAl in a diastereomeric ratio of 65:35 was treated with the recovered Betti base (under otherwise identical conditions), a $\left(1^{\prime} R, 3^{\prime} S, 11 R\right)-3 /\left(1^{\prime} R, 3^{\prime} S, 11 S\right)-3$ mixture was obtained in a ratio and yield similar to the ones obtained during the first run.

(20) Dong, Y.; Li, R.; Lu, J.; Xu, X.; Wang, X.; Hu, Y. An efficient kinetic resolution of racemic Betti base based on an enantioselective N,O-deketalization. J. Org. Chem. 2005, 70, 8617-8620. 